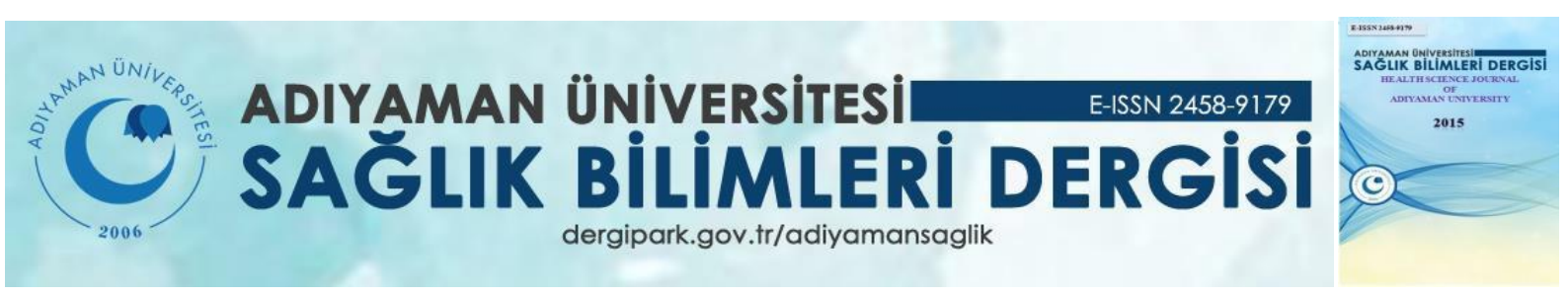

Araştırma/Research

The Investigation Preoperative Coagulation Values of Patients Undergoing Oral Surgical Procedure

\title{
Under Local Anesthesia
}

${ }^{1}$ Bilal Ege, ${ }^{2}$ Eldar Najafov

${ }^{1}$ Assistant Professor, Department of Oral and Maxillofacial Surgery, Faculty of Dentistry, Adiyaman University, Adiyaman, Turkey / miregein@gmail.com / ORCID ID: 0000-0002-1279-0893

${ }^{2}$ Assistant Professor, Department of Oral and Maxillofacial Surgery, Faculty of Dentistry, Kahramanmaras Sutcu Imam University, Kahramanmaras, Turkey / enajafov@ @su.edu.tr / ORCID ID: 0000-0001-5028-6084

\section{ABSTRACT}

Aim: The aim in this study was to investigate preoperative coagulation values of patients undergoing oral surgery under local anesthesia.

Material and Method: The study included 1598 patients who presented to the Department of Oral and Maxillofacial Surgery, Faculty of Dentistry at Adiyaman University between 2017 and 2018 for various reasons and underwent surgery under local anesthesia based on examination. The patients' age and gender as well as their coagulation values such as activated partial thromboplastin time (APTT), prothrombin time (PT) and international normalized ratio (INR) were recorded and analyzed statistically.

Results: The age range of the patients included in the study ranged between 11 and 92, and their mean age was $30.51 \pm 11.09$. Of these patients, $63.06 \%(n=1007)$ were female, and $36.94 \%(n=591)$ were male. The total number of female patients admitted was more than that of the male patients in terms of the distribution by gender. When the number of patients admitted were examined in terms of age groups $(0-20,21-40,41-60,>60)$, statistically significant differences were found especially between the ages $0-20$ and $21-40$ in both gender ( $p<$ $0.05)$. No significant differences were found in groups over the age of 40 ( $p>0.05)$. Values outside the normal range were observed in all of the coagulation values examined. Among these, APTT and PT (\%) values that were lower than the normal and INR and PT (s) values that were higher than the normal were found to prevail. An examination of these abnormal values in terms of gender revealed that the values other than PT (\%) were found to be statistically significantly higher in women, compared to men. In terms of age groups, these abnormal values belonging to the four coagulation parameters were found to be statistically significantly the highest among the people who were $21-40$ years old $(\mathrm{p}<0.001)$.

Conclusion: Taking preoperative coagulation tests prior to locally applied surgical procedures is especially important in patients for whom detailed medical history cannot be obtained.

Keywords: APTT; INR; PT; preoperative coagulation tests; oral surgery

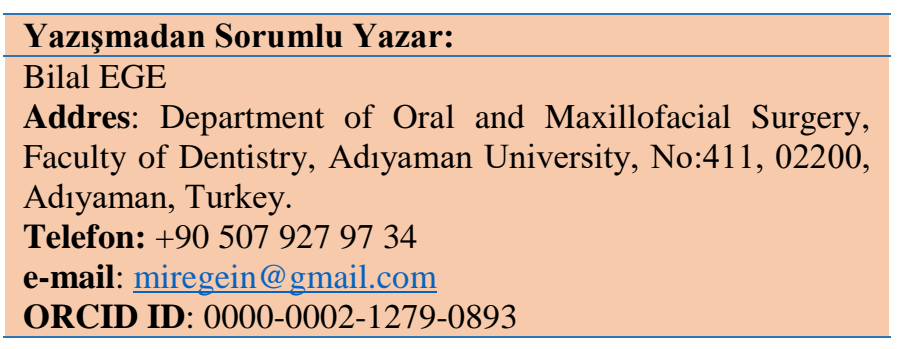

Doi: 10.30569.adiyamansaglik.609703

\begin{tabular}{ll}
\hline Geliş Tarihi : 23.08.2019 \\
\hline Kabul Tarihi : 08.11.2019 \\
\hline
\end{tabular}

Atıf Gösterimi/How to Cite: Ege B, Najafov E. The Investigation Preoperative Coagulation Values of Patients Undergoing Oral Surgical Procedure. Adıyaman Üni. Sağlık Bilimleri Derg. 2019; 5(3); 1696-1710. doi: 10.30569.adiyamansaglik.609703. 


\section{Lokal Anestezi Altında Oral Cerrahi Prosedür Uygulanan Hastaların Preoperatif Koagülasyon Değerlerinin Araştırılması}

\section{ÖZET}

Amaç: $\mathrm{Bu}$ çalışmanın amacı lokal anestezi altında oral cerrahi işlem geçiren hastaların preoperatif koagülasyon değerlerinin araştırılmasıdır.

Gereç ve Yöntem: Çalışmaya 2017-2018 tarihleri arasında Adıyaman Üniversitesi Diş Hekimliği Fakültesi Ağız, Diş ve Çene Cerrahisi Kliniği'ne çeşitli nedenlerden dolayı başvuran ve yapılan muayene sonucu kendisine lokal anestezi altında cerrahi girişim uygulanan 1598 hasta dahil edildi. Hastalara ait yaş, cinsiyet ve aktif parsiyel tromboplastin zamanı (APTT), protrombin zamanı (PT) ve uluslararası normalleştirilmiş oran (INR) gibi koagülasyon değerleri kaydedildi ve istatistiksel olarak analiz edildi.

Bulgular: Çalışmaya dahil edilen hastaların yaş aralığı 11-92 arasında değişmekteydi ve yaş ortalaması 30,51 $\pm 11,09$ idi. Bu hastaların \%63,06's1 (n=1007) kadın, \%36,94'ü (n=591) erkekti. Cinsiyete göre dağılımda başvuran toplam kadın hasta sayısı erkeklere kıyasla daha fazlaydı. Tüm hastalar alt yaş grupları (0-20, 21-40, 41-60, >60) bakımından incelendiğinde her iki cinsiyette özellikle 0-20 ile 21-40 yaş gruplarında istatistiksel olarak anlamlı farklılık bulundu $(\mathrm{p}<0.05)$. 40 yaş üstü gruplarda ise anlamlı farklılık bulunmadı ( $>00.05)$. İncelenen koagülasyon değerlerinin hepsinde normal sınırların dışında seyreden değerler görüldü. Bunlardan APTT ve PT (\%) değerlerinde düşük değerler; INR ve PT (sn) değerlerinde ise yüksek değerler sayıca daha fazla bulundu. Normal olmayan bu değerler cinsiyet bakımından incelendiğinde PT (\%) hariç diğerleri erkeklere nazaran kadınlarda istatistiksel olarak anlamlı şekilde daha fazla görüldügü bulundu. Dört koagülasyon parametresine ait normal olmayan bu değerler yaş grupları bakımından ise istatistiksel olarak anlamlı şekilde en fazla 21-40 yaş arasında görüldüğ̈̈ tespit edildi $(\mathrm{p}<0,001)$.

Sonuç: Lokal uygulanan cerrahi işlemler öncesinde preoperatif koagülasyon testlerinin alınması özellikle detaylı tıbbi anamnez alınamayan hastalarda önem arz etmektedir.

Anatar kelimeler: APTT; INR; PT; preoperatif koagülasyon testleri; oral cerrahi. 


\section{INTRODUCTION}

Congenital or acquired coagulopathies are some of the common health problem in the general population. Bleeding problems that are seen due to surgical interventions can be problematic in many patients with this condition. These problems also negatively affect the success of the surgical procedure and postoperative healing. For this reason, conducting a detailed preoperative assessment before surgical procedures is one of the effective methods to prevent such complications that may occur during and after surgery.

International Normalized Ratio (INR), Activated Partial Thromboplastin Time (APPT) and Prothrombin Time (PT) tests are some of the most common tests utilized in the diagnosis of coagulation diseases. APTT is used in order to monitor the intrinsic pathway in the hemostasis mechanism, and PT is used in order to monitor the extrinsic pathway (1). Manifestation of extrinsic and intrinsic pathways depends on clinical findings of blood diseases. Protein deficiencies due to the intrinsic pathway (Factor XII, prekallikrein, and high molecular weight quinogen (HMWK)) do not show signs of abnormal bleeding even after major surgical interventions, whereas protein deficiencies due to the extrinsic pathway (prothrombin, Factor V, VII, VIII, IX and X) lead to serious bleeding diatheses $(1,2)$.

Variations in values of such tests may be in physiological limits, as well as occasionally a precursor to some diseases. Such diseases may be hereditary or acquired. For example, a decreased APTT is observed in some types of cancer and in the use of a certain drug, whereas an increased APTT shows the potential presence of blood clotting disorders. It should also be noted that coagulation values may change depending on the use of anticoagulant drugs.

Oral surgical procedures under local anesthesia are dental treatments that are frequently administered in dentistry. However, a variety of medical problems, mainly bleeding, are encountered from time to time during or after surgical interventions. Preoperative medical assessments play a key role in reducing the complications that may occur. However, if patients do not know whether they have a disease such as a congenital bleeding problem, if they do not pay sufficient attention when the anamnesis is taken, if their level of literacy is not adequate, and for similar reasons, a preoperative anamnesis may be insufficient. This situation poses a risk for dentists and patients especially in terms of bloodborne diseases, mainly bleeding, in a profession like dentistry where almost all procedures are invasive.

Today, a variety of laboratory tests and examinations are performed in the preoperative period almost routinely in many diseases or interventions for treatment (3-5). Through such 
examinations, previously undiagnosed health problems can be detected, anesthesia and surgical approaches are reviewed, and undesirable conditions can also be prevented in the intraoperative and postoperative period. Although the access to health services has increased, bleeding problems are the leading medical problems currently encountered in dentistry. The most important reasons for this condition, we believe, stem from the fact that adequate and inclusive anamneses cannot be taken from patients, as well as the fact that the necessary examinations and tests are not routinely carried out or cannot be carried out, especially prior to surgical procedures performed under local anesthesia.

The aim of this study was to examine the preoperative INR, APPT and PT values of the patients who presented to the dental clinic and underwent dental surgery under local anesthesia for various reasons and to assess them for the risk of bleeding.

\section{MATERIALS AND METHODS}

This study included 1598 patients who presented to the Department of Oral and Maxillofacial Surgery, Faculty of Dentistry at Adiyaman University between 2017 and 2018 and who were scheduled an appointment for a local surgery and underwent a surgical intervention based on examinations, for various reasons (impacted tooth extraction, dental implant, odontogenic cyst surgery). Prior to the study, approval was obtained from the Ethics Committee for NonInterventional Studies of Adiyaman University (Approval number: 2019/4-10). And following that, coagulation values - one of the tests routinely requested from patients in the preoperative period - and clinical and demographic data were examined retrospectively. Patients who coagulation values were not specified and test results were not available were excluded from the study.

Coagulation tests were carried out, and analysis results were assessed at the Microbiology Laboratory of Adiyaman University Training and Research Hospital prior to the surgical procedure. For the assessment of secondary hemostasis APTT, PT and INR were assessed. For these analyses, venous blood was drawn from the patients in the atraumatic form into 1/9 of blue-lid tubes containing 3.2\% sodium citrate before the procedure. Attention was paid not to keep the blood waiting and not to allow clots to form in the blood. After the samples were centrifuged for 10 minutes in $2500 \mathrm{~g}$, their plasm was separated, and they were studied without delay. 
The samples taken during the analysis process were studied in a coagulation analyzer according to the recommendations of the company producing the analyzer, by using the standard methods indicated by the manufacturer. In accordance with the manufacturer's kit prospectus, normal values were accepted to be 26.5-40 s for APTT, 70-120\% for PT (\%), 0.9-1.2 for INR, and finally $11-16.5 \mathrm{~s}$ for PT (s). The distribution of coagulation values according to age and gender were examined for each patient.

\section{Statistical Analysis}

The Windows SPSS 20.0 software program was used for statistical analysis. Data were transferred to the computer environment. Categorical variables were compared by using chisquare tests and expressed in counts and percentages. A p value $<0.05$ was considered statistically significant.

\section{RESULTS}

This study included 1598 patients (591 males and 1007 females) in the age range of 11-92 years. preoperative coagulation values of all patients were existent. The data that were obtained were in the range of 9.8-72 s for the APTT values, 12.3-139\% for the PT (\%) values, 0.8-3.6 for the INR values, and 4.3-34.8 s for the PT (s) values (Table 1).

Table 1. The normal range of the examined coagulation values and the determined minimum and maximum values

\begin{tabular}{lcccc}
\hline & APTT (s) & PT (\%) & INR & PT (s) \\
\hline Normal Range & $26,5-40$ & $70-120$ & $0,9-1,2$ & $11-16,5$ \\
Measured min-max values & $9.8-72$ & $12.3-139$ & $0.8-3.6$ & $4.3-34.8$ \\
\hline
\end{tabular}

APTT: activated partial thromboplastin time

PT: Prothrombin time

INR: international normalized ratio

Considering the distribution of patients according to gender, the number of female patients presenting to the clinic was statistically significantly higher than that of male patients $(\mathrm{p}<$ 0.001). In terms of age groups, statistically significant differences were found between men and women only in the age groups of 0-20 and 21-40. The number of female patients in these two age groups was more than that of male patients $(\mathrm{p}<0.001)$. No significant difference was 
observed among those who were 40 years old or older $(\mathrm{p}>0.05)$ (Table 2). All age groups were found to be statistically significantly different from each other within gender $(\mathrm{p}<0.001)$. Both among males and females, especially between the ages of 21 and 40, significantly more people presented to the clinic in comparison to other age groups (Table 2).

Table 2. Distribution of the patients according to age groups and gender

\begin{tabular}{ccccc}
\hline \multicolumn{5}{c}{ Gender } \\
\hline Age groups & Male $(\boldsymbol{n})$ & Female $(\boldsymbol{n})$ & Total & $\mathrm{P}^{\phi}$ \\
$\mathbf{0 - 2 0}$ & 66 & 133 & 199 & $<\mathbf{0 . 0 0 1}$ \\
$\mathbf{2 1 - 4 0}$ & 419 & 743 & 1162 & $<\mathbf{0 . 0 0 1}$ \\
$\mathbf{4 1 - 6 0}$ & 89 & 102 & 191 & 0,885 \\
$>\mathbf{6 0}$ & 17 & 29 & 46 & 0,077 \\
$\mathbf{P}^{\phi}$ & $<\mathbf{0 , 0 0 1}$ & $\boldsymbol{< 0 , 0 0 1}$ & $<\mathbf{0 , 0 0 1}$ & \\
Total & $\mathbf{5 9 1}$ & $\mathbf{1 0 0 7}$ & $\mathbf{1 5 9 8}$ & $<\mathbf{0 . 0 0 1}$ \\
\hline
\end{tabular}

क: Chi Square test used.

APTT values were found to be within normal limits in $94.8 \%$ of the patients presenting to the clinic $(n=1514)$, high in $1.9 \%(n=31)$, and low in 3.3\% $(n=53)$. PT $(\%)$ values were found to be within normal limits in $95.6 \%$ of the patients $(n=1527)$, high in $2 \%(n=33)$, and low in $2.4 \%(\mathrm{n}=38)$. INR values were found to be within normal limits in $94.3 \%$ of the patients $(\mathrm{n}=$ 1507), high in $1.9 \%(n=85)$, and low in $0.4 \%(n=6)$. PT (s) values were found to be within normal limits in $97 \%$ of the patients $(n=1550)$, high in $2.6 \%(n=41)$, and low in $0.4 \%(n=7)$ (Table 3).

Table 3. Normal, high and low coagulation values and percentile distributions

\begin{tabular}{lcccc}
\hline & APTT & PT(\%) & INR & PT (s) \\
& n / \% & n / \% & n / \% & n / \% \\
\hline Normal & $1514 / \% 94,8$ & $1527 / \% 95,6$ & $1507 / \% 94,3$ & $1550 / \% 97$ \\
High & $31 / \% 1,9$ & $33 / \% 2$ & $85 / \% 5,3$ & $41 / \% 2,6$ \\
Low & $53 / \% 3,3$ & $38 / \% 2,4$ & $6 / \% 0,4$ & $7 / \% 0,4$ \\
Total & $1598 / \% 100$ & $1598 / \% 100$ & $1598 / \% 100$ & $1598 / \% 100$ \\
\hline
\end{tabular}

APTT: activated partial thromboplastin time

PT: Prothrombin time

INR: international normalized ratio

Statistically significant differences were found in terms of APTT, INR and PT (s) when the coagulation values which were not within normal boundaries - i.e. high or low - were compared quantitatively ( $\mathrm{p}<0.05)$. There was no significant differences in PT $(\%)$ values; the low and high values followed a close course $(\mathrm{p}>0.05)$ (Table 4) (Figure 1). 
Table 4. Homogenous distribution of APTT, PT and INR values determined to be outside normal boundaries (high or low)

\begin{tabular}{ccccc}
\hline & $\boldsymbol{A P T T}$ & $\boldsymbol{P T}(\boldsymbol{\%})$ & $\boldsymbol{I N R}$ & $\boldsymbol{P T}(\boldsymbol{s})$ \\
& $\boldsymbol{n}$ & $\boldsymbol{n}$ & $\boldsymbol{n}$ & $\boldsymbol{n}$ \\
\hline High & 31 & 33 & 85 & 41 \\
Low & 53 & 38 & 6 & 7 \\
Total & 84 & 71 & 91 & 48 \\
$\mathrm{P}^{\phi}$ & 0,016 & 0,553 & $<\mathbf{0 , 0 0 1}$ & $<0,001$ \\
\hline
\end{tabular}

Chi Square test used.

APTT: activated partial thromboplastin time

PT: Prothrombin time

INR: international normalized ratio

Moreover, an examination of the distribution of these variables, which were not within normal limits, according to gender showed that there were statistically significantly more coagulation values that were measured to be low and high, except for the PT (\%) value, among females compared to males ( $\mathrm{p}<0.001, \mathrm{p}=0.005, \mathrm{p}=0.021$ ) (Table 5) (Figure 2). In terms of the PT $(\%)$ value, there was no significant difference $(\mathrm{p}=0.722)$.

Table 5. Distribution of APTT, PT and INR values determined to be outside normal boundaries (high or low) according to gender

\begin{tabular}{|c|c|c|c|c|}
\hline & & Male & Female & $\boldsymbol{P}^{\phi}$ \\
\hline \multirow[t]{3}{*}{$A P T T$} & High $(n=31)$ & $14(\% 45,2)$ & $17(\% 54,8)$ & \\
\hline & Low $(n=53)$ & $7(\% 13,2)$ & $46(\% 86,8)$ & \\
\hline & Total $(n=84)$ & $21(\% 25)$ & $63(\% 75)$ & $<0,001$ \\
\hline \multirow[t]{3}{*}{$P T(\%)$} & High $(n=33)$ & $20(\% 60,6)$ & $13(\% 39,4)$ & \\
\hline & $\operatorname{Low}(n=38)$ & $14(\% 36,8)$ & $24(\% 63,2)$ & \\
\hline & Total $(n=71)$ & $34(\% 47,9)$ & $37(\% 52,1)$ & 0,722 \\
\hline \multirow[t]{3}{*}{ INR } & High $(n=85)$ & $31(\% 36,5)$ & $54(\% 63,5)$ & \\
\hline & $\operatorname{Low}(n=6)$ & $1(\%$ 16,7) & $5(\% 83,3)$ & \\
\hline & Total $(n=91)$ & $32(\% 35,2)$ & $59(\% 64,8)$ & 0,005 \\
\hline \multirow[t]{3}{*}{$P T(s)$} & High $(n=41)$ & $14(\% 34,1)$ & $27(\% 65,9)$ & \\
\hline & Low $(n=7)$ & $2(\% 28,6)$ & $5(\% 71,4)$ & \\
\hline & Total $(n=48)$ & $16(\% 33,3)$ & $32(\% 66,6)$ & 0,021 \\
\hline
\end{tabular}

${ }^{\phi}$ : Chi Square test used.

APTT: activated partial thromboplastin time

PT: Prothrombin time

INR: international normalized ratio

Based on the examination of all coagulation values that were observed not to be within normal limits in terms of age, it was found that all of the high and low values of APTT, INR, PT (\%) 
and PT (s) were statistically significantly higher in the age range of 21-40 compared to those of the other age ranges $(\mathrm{p}<0.001)$ (Table 6) (Figure 3).

Table 6. Distributions and significance levels of APTT, PT and INR values determined to be high or low according to age

\begin{tabular}{ccccc}
\hline $\begin{array}{c}\text { Age } \\
\text { groups }\end{array}$ & $\boldsymbol{A P T T}(\boldsymbol{H} / \mathbf{L})$ & $\boldsymbol{P T}(\boldsymbol{\%})$ & $\boldsymbol{I N R}$ & $\boldsymbol{P T}(\boldsymbol{s})$ \\
\hline $\mathbf{0 - 2 0}$ & $16(7 / 9)$ & $8(2 / 6)$ & $\boldsymbol{T}(\boldsymbol{H} / \mathbf{L})$ & $\boldsymbol{T}(\boldsymbol{H} / \mathbf{L})$ \\
$\mathbf{2 1 - 4 0}$ & $49(19 / 30)$ & $48(21 / 27)$ & $66(61 / 5)$ & $33(28 / 5)$ \\
$\mathbf{4 1 - 6 0}$ & $12(4 / 8)$ & $12(8 / 4)$ & $8(7 / 1)$ & $4(3 / 1)$ \\
$>\mathbf{6 0}$ & $7(1 / 6)$ & $3(2 / 1)$ & $3(3 / 0)$ & $3(3 / 0)$ \\
Total & $84(31 / 53)$ & $71(33 / 38)$ & $91(85 / 6)$ & $48(41 / 7)$ \\
$\mathbf{P}^{\phi}$ & $<\mathbf{0 , 0 0 1}$ & $<\mathbf{0 , 0 0 1}$ & $<\mathbf{0 , 0 0 1}$ & $<\mathbf{0 , 0 0 1}$ \\
\hline . Chi Square test used. & & & \\
T: Total; H: High; L: Low & & &
\end{tabular}

\section{DISCUSSION}

Dentists work on many different groups of systemic diseases throughout their professional lives, and usually almost all of the dental treatments they administer consist of invasive interventions applied on soft or hard tissues. Medical and dental anamneses to be taken from patients prior to treatment are very important in order not to have adverse clinical presentations that may occur during or after treatment.

Considering that surgical interventions, particularly oral, dental and maxillofacial surgeries, are quite frequent in dental practice and considering that in almost all of these services, patients are treated as outpatients, patients' hemorrhage-related systemic conditions becomes more of an issue. This is because when assessed clinically, hemorrhages lasting more than 12 hours, bleedings that happen with no reason or when brushing teeth, hematomas or ecchymoses occurring after oral surgery can be observed. Therefore, patients' problems related to previously experienced bleeding, use of anticoagulant drugs, alcohol and drug addiction and blood diseases that can lead to liver damage should be questioned, and genetic diseases that run in the family should be investigated. Otherwise, serious hemorrhages that may result in shock or even death can develop in patients with a tendency to bleed during or after dental treatments performed without carrying out a proper anamnesis and clinical examination. The best approach to this issue is to carefully examine patients who have genetic or acquired bleeding disorders or who 
use anticoagulant medication, and to ask for hematologist consultation in addition to laboratory tests from patients (6).

The aim of preoperative hematologic laboratory tests is to determine if there is any coagulation disorder in patients who are scheduled to undergo surgical procedures, and to ensure the determination and prevention of complications that may develop in the postoperative period when assessing patients planned to undergo an elective surgical intervention (7-9). In this way, possible problems in the hemostasis mechanism are observed in the preoperative period, and oral surgical procedures are achieved with confidence.

Dentists are faced with having to perform small or large invasive oral surgery interventions in many patients with a tendency to bleed. Indications for surgical intervention in such patients are sometimes emergent, but sometimes elective. In such cases, patients can be assessed in terms of postoperative bleeding in most health centers with the help of tests such as preoperative coagulation and full blood count.

In dentistry, however, the majority of surgical procedures performed under local anesthesia are performed under clinical conditions usually without carrying out coagulation tests or due to the failure to obtain them for various reasons. This makes the situation even worse in the case of risk of bleeding in patients from whom detailed anamneses cannot be taken or who are not knowledgeable about their current systemic conditions. In present study, it was aimed to construct a general profile of our patients in terms of coagulation values and to predict whether there was any risk for bleeding in this study where retrospectively assessed the preoperative analysis results of the patients whom had operated on for a variety of reasons under local anesthesia.

It has been reported in a number of studies in the literature that it is very unlikely to detect existing abnormalities in patients through preoperative laboratory tests, and very few of these abnormalities affect treatment (10-12). It has also been emphasized that this situation also applies to preoperative coagulation tests. It has been emphasized that the efficacy of coagulation tests in detecting patients at high risk of bleeding is questionable, and for this reason, they do not need to be carried out in patients with a history of bleeding or who do not have an inherited tendency to bleed (13-16). In this study, it is believed that knowing preoperative coagulation values can prove to be important for oral surgeries because of the reasons such as the fact that almost all of the treatments are outpatient treatments, that it is not possible to hospitalize 
patients in an emergency, and that especially elderly patients who admitted to department of oral and maxillofacial surgery are resistant to provide detailed medical history.

To that end, coagulation values such as APTT, PT and INR were examined in the present study. From among those, APTT is a test that is used in assessing patients who are suspected of lack of factors belonging to the intrinsic and common pathways of the coagulation system. During this test, an activator such as a phospholipid, calcium and ellagic acid or kaolin is added to the plasma, and the elapsed time until the formation of a fibrin clot is measured through the intrinsic pathway. This test is influenced by a number of factors such as Factors II, VIII, IX, X, XI and XII, and fibrinogen. For this reason, APTT sensitivity varies depending on the severity of the factor deficiency. If the deficiency is severe, the APTT test gives a result that is $100 \%$ accurate, and if there is a moderate level of factor failure, it gives a result that is $90 \%$ accurate (1). PT is a test used for assessing the extrinsic and common pathway of clotting. In this test, calcium and thromboplastin are added to the plasma and the time elapsed until the formation of a fibrin clot is measured through the extrinsic pathway. PT is influenced by Factors V, VII and $\mathrm{X}$, prothrombin, and fibrinogen levels. Another important issue is that PT results show varying levels of sensitivity to thromboplastin reagents produced by different producers. To avoid this problem, the World Health Organization (WHO) has begun to use the International Normalized Ratio (INR) value to create a standard approach (17). INR is the ratio of the patient's PT value to the geometric mean of the PT value of the patient who does not use the laboratory-determined anticoagulant. Another value that was examined in present study was INR.

Results that do not fall between normal values based on the result of analysis methods that are carried out do not necessarily show that the patient has a problem of coagulation. This is because conditions such as heparin contamination and the use of defective devices and a prolonged tourniquet can cause a patient to have irregular coagulation results (18). For instance, differences between instruments used to measure PT and APTT values and the use of different reagents cause significant inconsistencies among results (19). Therefore, in present study, it was included the results obtained from a single center and was not assess the test results from different centers. For the coagulation values, this reference range was standardized to be 26.5$40 \mathrm{~s}$ for APTT, 0.9-1.2 for INR, 70-120\% for PT (\%), and 11-16.5 s for PT (s).

Under normal conditions, APTT prolongation does not occur until the level of coagulation factors falls below 15-30\% (1). However, in this study the APTT duration was found to be extended compared to the normal duration in $1.9 \%$ of the 1598 patients $(n=31)$, and it was 
found to occur in shorter periods in $3.3 \%(\mathrm{n}=53)$. For this reason, it was thought that the coagulation factor levels may be significantly decreased in 31 patients for whom this period had been prolonged. Similarly, the prolongation of PT is not observed until Factors V, VII and $\mathrm{X}$, prothrombin and fibrinogen levels are reduced to below $10 \%$ of normal. In the present study, the PT (s) values were found to be shortened in $0.4 \%$ of all patients $(n=7)$, whereas they were found to be prolonged in $2.6 \%(n=41)$. This result suggested that the related factor levels might have fallen below the critical level among patients who had similarly prolonged PT values. INR was found to be high in $5.3 \%$ of the patients $(\mathrm{n}=85)$, and this value was found to be lower than normal in $0.4 \%(n=6)$. It is thought that this difference in the value of INR varies in direct proportion to PT. Today, INR is used very often to assess the risk of bleeding particularly in patients who use anticoagulant drugs (17). In terms of dental procedures, if INR values are within limits that are safe, routine dental interventions can be performed by maintaining medication.

In the literature, Lu et al. (20) have investigated tooth extractions and subsequent bleeding in patients on warfarin and were treated with anticoagulant medication. Their study included 60 patients who used warfarin and 183 patients treated with anticoagulants, and 1088 healthy people were included as a control group. Although they found the incidence of postoperative hemorrhage in the patients using warfarin to be high compared to that in the other two groups, they did not find a statistically significant difference. The authors also determined that this difference was not related to the value of INR and the type of tooth extraction (20). However, the general opinion on this topic is that the INR value should not be higher than 3.5 on the day of surgery $(21,22)$. In our patients, the highest INR value measured accordingly was determined as 3.6. However, it was not known whether there was a problem with postoperative hemorrhage in patients with an INR value that was higher than normal. This adverse situation was due to the fact that this study was a retrospective study. Therefore, planning a study with a prospective design can give more accurate results in terms of benchmarking. It is hoped that this present study will contribute to the literature in terms of offering a reference interval and general incidence information about preoperative coagulation values especially of patients who are to be treated with oral surgery under local anesthesia.

There were significantly more values of coagulation data, such as APTT, PT and INR, that were above the normal range than the values that were below the normal range. In the present study conducted retrospectively, the absence of anamnesis data restricts the understanding of the causes of coagulation values that were determined to be higher or lower than the normal range. 
However, for a clearer understanding of the causes of this situation, a detailed medical history of the patients should be recorded. This is because whether the coagulation values examined are low or high is affected by many etiologic factors, such as anticoagulant medication, bleeding diseases, levels of associated factors, presence of a previous surgical operation, alcohol use or liver diseases.

It has also been reported in the literature that it is difficult to detect congenital bleeding problems that are rarely seen by existing coagulation tests $(23,24)$. Beloeil et al. (25) investigated the relationship between preoperative coagulation and postoperative bleeding. They observed that the incidence of postoperative bleeding was very low, and they stated that routine laboratory coagulation tests were not necessary and had no clinical effect. $\mathrm{Ng}$ et al. (26) examined the preoperative coagulation values of 824 patients who underwent major surgeries. They showed that there was a greater variability in the number of platelets and fresh frozen plasma transfusions needed by people who varied in coagulation tests. However, they did not find any significant difference in terms of blood loss and bleeding complications. Because tonsillectomy, which is a common pediatric surgical intervention, has a high incidence of postoperative bleeding, the preoperative hemostasis test can be performed in this process. Nevertheless, Saw et al. (27) have suggested that the benefits of preoperative coagulation tests are questionable because postoperative bleeding is seen in less than $20 \%$ of children with clotting problems. However, we think that coagulation tests will be beneficial in identifying acquired bleeding problems, especially the use of anticoagulant medication.

It has also been emphasized in the literature that coagulation values may vary according to gender and age groups. Buldu et al. (28) reported that APTT, PT and INR values showed significant differences between the pediatric age group and adults. The authors also reported that results of APTT in children aged 1-3 years and results of PT and INR in children aged 610 years differ significantly from those of adults (28). Unlike the study of Buldu et al., in this study, no comparison was made as children and adults, but rather, the distribution of these values was investigated according to consecutive age groups.

Consequently, high and low coagulation values that did not show normal distribution were found to be significantly higher especially in the age range of 21-40 years than in other age groups. Buldu et al. (28) also found that PT and INR values in 4 different age groups showed significant differences in both male and female children depending on gender. It was found that abnormal APTT, PT (sec), INR values were statistically more common among women in this 
study. However, unlike in the study of Buldu et al., in the present study the population of the patients was not evenly distributed across the age ranges, and the majority of patients were in the age range of 21-40 and females, which may be considered to have affected these outcomes.

It should be noted that coagulation tests may not always be able to detect underlying bleeding diseases when all these results are considered together. For example, in people with von Willebrand disease, PT and APTT values can be seen at normal level unless clinically distinct symptoms occur (29). Even if there are no problems in coagulation values, it should be remembered that clotting problems may occasionally be experienced by such patients. Nagarakanti et al. (30) have reported that although a person was systemically healthy and his preoperative coagulation values were normal, there was an unstoppable bleeding complaint after gingival excision. They reported that the person was diagnosed with hemophilia A after consultation.

In the literature, coagulation tests are not theoretically recommended for patients who describe themselves as healthy and have no previous history of hemorrhage and do not have familial factors. However, we think that it is more appropriate to perform the necessary coagulation tests in the health centers where outpatient services are performed, considering the age, sex, and systemic health status of the patients. Therefore, the results of this study that retrospectively analyzed coagulation values in the patient population undergoing oral surgery, provide important information and rates to physicians in terms of undesired bleeding. But more accurate results in terms of bleeding will be obtained when patients' preoperative coagulation values, their systemic anamnesis data, and their postoperative bleeding follow-ups are assessed altogether.

Ethical Approval: Ethics committee approval was received for this study from Adiyaman University (Approval number: 2019/4-10).

Author Contributions: Conception - B.E.; Design - B.E., E.N.; Supervision - E.N.; Materials - B.E.; Data Collection and/or Processing - - B.E.; Analysis and/or Interpretation - E.N.; Literature Review - E.N.; Writer - B.E., E.N.; Critical Review - B.E., E.N.

Conflict of Interest: No conflict of interest was declared by the authors.

Financial Disclosure: No financial disclosure was declared by the authors 


\section{REFERENCES}

1. Rodgers GM, Bithell TC. The diagnostic approach to the bleeding disorders. In: Lee GR, Foerster J, Lukens J, Paraskevas F, Greer JP, Rodgers GM, Eds. Wintrobe's Clinical Hematology, Lippincott Williams \& Wilkins, 1999: 1557-1578.

2. Seligsohn U, Coller BS. Classification, clinical manifestations and evaluation of disorders of hemostasis. In: Beutler E, Lichtman MA, Coller BS, Kipps TJ, Seligsohn U, Eds. William's Hematology, McGraw Hill, 2001: 1471-1478.

3. Roizen MF, Foss JF, Ficsher SP. Preoperative evaluation. In: Miller RD Eds. Anesthesia, Churchill Livingstone, 2000: 824-883.

4. Finegan BA, Rashiq S, McAlister FA, O'Connor P. Selective ordering of preoperative investigations by anesthesiologists reduces the number and cost of tests. Can J Anaesth 2005; 52: 575-580.

5. Imasogie N, Wong DT, Luk K, Chung F. Elimination of routine testing in patients undergoing cataract surgery allows substantial saving in laboratory costs. A brief report. Can J Anaesth 2003; 50: 246-248.

6. Coskunses FM, Dogan O. Dental management of patients with bleeding disorders. Cumhuriyet Dent J 2013; 16: 83-90.

7. Nardella A, Pechet L, Synder LM. Continuous improvement, quality control, and cost containment in clinical laboratory testing. Effects of establishing and implementing guidelines for preoperative tests. Arch Pathol Lab Med 1995; 119: 518-522.

8. Dzankic S, Pastor D, Gonzalez C, Leung JM. The prevalence and predictive value of abnormal preoperative laboratory tests in elderly surgical patients. Anesth Analg 2001; 93: 301-308.

9. Francis CW, Kaplan KL. Hematologic problems in the surgical patient: Bleeding and thrombosis. In: Hoffman R, Benz EJ, Shattil SJ, Furie B, Cohen HJ, Silberstein LE, McGlave P Eds. Hematology Basic Principles and Practice, Churchill Livingstone, 2000: 2381-2391.

10. Adams JG Jr, Weigelt JA, Poulos E. Usefulness of preoperative laboratory assessment of patients undergoing elective herniorrhaphy. Arch Surg 1992; 127: 801-805.

11. Kaplan EB, Sheiner LB, Boeckmann AJ, Roizen MF, Beal SL, Cohen SN, et al. The usefulnes of preoperative laboratory screening. JAMA 1985; 253: 3576-3581.

12. Perez A, Planell J, Bacardaz C, Hounie A, Franci J, Brotons C, et al. Value of routine preoperative tests: a multicentre atudy in four general hospitals. Br J Anaesth 1995; 74: 250-256.

13. Asaf T, Reuveni H, Yermiahu T, Leiberman A, Gurman G, Porat A, et al. The need for routine preoperative coagulation screening tests (prothrombin time PT/partial thromboplastin time PTT) for healthy children undergoing elective tonsillectomy and/or adenoidectomy. Int J Ped Otorhinolaryngol 2001; 61: 217-222.

14. Close HL, Kryzer TC, Nowlin JH, Alving BM. Hemostatic assessment of patients before tonsillectomy: a prospective study. Otolaryngol Head Neck Surg 1994; 111: 733-738.

15. Houry S, Georgeac C, Hay JM, Fingerhut A, Boudet MJ. A prospective multi-center evaluation of preoperative hemostatic screening tests. The French Associations for Surgical Research. Am J Surg 1995; 170: 19-23.

16. Burk CD, Miller L, Handler SD, Cohen AR. Preoperative history and coagulation screening in children undergoing tonsillectomy. Pediatrics 1992; 89: 691-695.

17. World Health Organization (WHO). WHO Expert Committee on Biological Standardization-ThirtyThird report. Annex 3, WHO Technical Report Series, no.687-Requirements for thromboplastins and plasma used to control oral anticoagulant therapy, 1983 
18. Magnette A. Chatelain M, Chatelain B, Ten Cate H, Mullier F. Pre-analytical issues in the haemostasis laboratory: guidance for the clinical laboratories. Thromb J 2016; 14: 49.

19. Funk DM. Coagulation assays and anticoagulant monitoring. Haematology Am Soc Hematol Educ Program 2012; 2012: 460-465.

20. Lu SY, Lin LH, Hsue SS. Management of dental extractions in patients on warfarin and antiplatelet therapy. J Fromos Med Assoc. 2018; 117: 979-986.

21. van Diermen DE, van der Waal I, Hoogstraten J. Management recommednations for invasive dental treatment in patients using oral antithrombotic medication, including novel oral anticoagulants. Oral Surg Oral Med Oral Pathol Oral Radiol 2013; 116: 709-716.

22. Douketis JD, Spuropoulos AC, Spencer FA, Mayr M, Jaffer AK, Eckman MH, et al. Perioperative management of athithrombotic therapy: antithrombotic therapy and prevention of thrombosis: American College of Chest Physicians evidence-based clinical practice guidelines. Chest 2012; 141: e326S-e350S.

23. Sadler JE, Manucci PM, Berntorp E, Bochkov N, Boulyjenkov V, Ginsburg D, et al. Impact, diagnosis and treatment of von Willebrand disease. Thromb Haemost 2000; 84: 160-174.

24. Bolton-Maggs PHB, Perry DJ, Chalmers EA, Parapia LA, Wilde JT, Williams MD, et al. The rare coagulation disorders-review with guidlines for management from the United Kingdom Haemophilia Centre Doctors Organisation. Haemophilia 2004; 10: 593-628.

25. Beloeil H, Ruchard D, Dreniak N, Molliex S. Overuse of preoperative labortory coagulation testing and ABO blood typing: a French national study. Br J Anaesth 2017; 119: 1186-1193.

26. $\mathrm{Ng} \mathrm{KF}$, Lai KW, Tsang SF. Value of preoperative coagulation tests: reappraisal of majör noncardiac surgery. World J Surg 2002; 26: 515-520.

27. Saw PH, Reynolds S, Gunawardena S, Krishnamurti L, Ritchey AK. The prevalence of bleeding disorders among healthy pediatric patients with abnormal preprocedural coagulation studies. J Pediatr Hematol Oncol 2008; 30: 135-141.

28. Buldu S, Halıcı C, Narin F, Elmalı F. Determination of Pediatric Reference Intervals for Three Coagulation Tests in Widespread Use for City of Kayseri Population. Turk J Biochem 2012; 37: 362367.

29. Laffan MA, Lester W, O’Donnell JS, Will A, Tait RC, Goodeve A. The diagnosis and management of won Willebrand disease: a United Kingdom Haemophilia Centre Doctors Organization guideline approved by the British Committee for Standards in Haematology. Br J Haematol 2014; 167: 453-465.

30. Nagarakanti S, Sappati H, Gunupati S, Ramesh Reddy BV, Chava VK.. Dental management of a patient with incidentally detected hemophilia: Report of a clinical case. J Indian Soc Periodontol 2019; 23: 281283. 